\title{
Inhibition of Amyloidosis Using Low-Molecular-Weight Heparins
}

\author{
Hong $\mathrm{Zhu}^{1}$, Jin $\mathrm{Yu}^{1}$, and Mark S. Kindy ${ }^{1,2,3}$ \\ ${ }^{1}$ Department of Biochemistry, University of Kentucky, Lexington, Kentucky, USA \\ ${ }^{2}$ Stroke Program of the Sanders-Brown Center on Aging, University of Kentucky, Lexington, Kentucky, USA \\ ${ }^{3}$ Veterans Affairs Medical Center, Lexington, Kentucky, USA \\ Accepted June 20, 2001
}

\begin{abstract}
Background: Amyloid diseases are characterized by the tissue deposition of extracellular proteinaceous material, which results in organ dysfunction and death. Colocalization of heparan sulfate (HS) proteoglycans to amyloid deposits suggests that they may be an early event in amyloid formation and play an important role in fibril formation. Structural analysis has demonstrated that HS interacts with amyloidogenic proteins resulting in structural changes that allow for an increase in $\beta$-sheet content, possibly enhancing fibrillogenesis. Recent studies have shown that small-molecule anionic sulfonates or sulfates can arrest inflammation-associated (AA) amyloid induction.

Materials and Methods: In the present study, we exam-
\end{abstract} ine the effect of low-molecular-weight heparins (LMWHs) on the development of amyloid in the mouse model of AA amyloid. In addition, in vitro fibril formation assays were performed to determine the effect of LMWHs on fibrillogenesis.

Results: Injection of mice with clinically relevant doses of LMWHs (enoxaparin and dalteparin) demonstrated a reduction in AA amyloid deposition. These compounds were capable of arresting the progression of AA amyloid and eventually resulting in regression of the amyloid deposits. In vitro analysis indicated that LMWHs prevented AA and $\mathrm{A} \beta$ peptide fibril formation by impeding the structural changes necessary for fibril formation.

Conclusions: Our findings suggest that the LMWHs may provide beneficial effects against the development of amyloidoses, including Alzheimer's disease.

\section{Introduction}

One of the hallmarks of amyloid diseases is the extracellular accumulation of proteinaceous fibrillar tissue deposits (1-3). These extracellular deposits of proteins are characterized by the insoluble aggregation of protease-resistant material that is thought to contribute to the pathogenesis of many amyloid diseases (4). $\mathrm{A} \beta$-peptide of Alzheimer's disease is the most common form of amyloid disorder; however, there are many other pathologic entities that fall into this classification. Primary amyloidosis or light chain amyloid (AL), secondary or inflammationassociated amyloid (AA), amylin or islet amyloid polypeptide (IAPP) amyloid associated with noninsulin-dependent diabetes mellitus, and senile systemic amyloid (transthyretin, TTR) are several of at least 20 different amyloid diseases (5). In addition, a number of common elements have been identified as being important in the process of amyloid deposition (6). These include serum amyloid P (SAP) component, apolipoprotein E (apoE), and heparan sulfate (HS) proteoglycans (HSPG, specifically perlecan), which appear to facilitate amyloid formation (7-9). Recent studies have demonstrated the significance of common components in the process

Address correspondence and reprint requests to: Mark S. Kindy, Department of Biochemistry, University of Kentucky, 800 Rose Street, Lexington, KY 40536. Phone: (859) 257-5560; fax: (859) 257-8990; e-mail: mskindy@pop.uky.edu of amyloid deposition. In vitro studies have shown that SAP and apoE can stimulate as well as reduce the fibril formation of $A \beta$ peptide (10-12). Subsequently, mice deficient in SAP and apoE have a decrease in amyloid accumulation in $\mathrm{AA}$ and $\mathrm{A} \beta$ amyloid models $(7,8,13)$.

Highly sulfated glycosaminoglycans are present in all forms of amyloid identified. HSPGs are a fundamental part of the basement membrane structure and may provide an initiation point for amyloid fibrillogenesis (14). Studies have shown that perlecan mRNA and protein are increased early during amyloid induction and are found concurrently deposited with AA amyloid (15). This relationship suggests that HSPGs may play a substantial role in amyloidogenesis. Kisilevsky et al. (16) proposed that inhibition of precursor protein interaction with HSPG would alter fibrillogenic potential and reduce amyloid deposition. Using smallmolecular-weight sulfonates and sulfates, not only was AA amyloid progression retarded, but these molecules enhanced clearance of established amyloid fibrils.

With this in mind, we reasoned that heparins might be able to have a similar effect on amyloid formation. Injection of mice with the low-molecularweight heparins (LMWH) enoxaparin and dalteparin resulted in the dramatic inhibition of amyloidogenesis in the mouse AA amyloid model. In addition, the LMWHs were capable of reversing 
the process of amyloidosis and inhibiting fibril formation by blocking the formation of $\beta$-pleated structures. These studies suggest that LMWHs may provide a potential therapeutic strategy for treatment of amyloid diseases, specifically Alzheimer's disease.

\section{Materials and Methods}

Reagents and Animals

All reagents used in this study were of the highest quality available from Sigma Chemical Co. (St. Louis, MO, USA) unless otherwise stated. SAA antibodies were prepared from acute-phase SAA protein as described previously (5). C57BL/6 mice were obtained from Harlan Sprague Dawley (Indianapolis, IN, USA).

\section{Low-Molecular Weight Heparins}

In the present study, dalteparin sodium injection (Fragmin, Pharmacia-Upjohn, Kalamazoo, MI) average molecular weight 5000 was prepared from a stock solution of $16 \mathrm{mg} / 0.2 \mathrm{ml} \mathrm{(2500} \mathrm{anti} \mathrm{factor} \mathrm{Xa}$ International Units). The solution was diluted in saline at $\mathrm{pH} 7.0$ to a final dose of $0.006 \mathrm{mg} / 25 \mathrm{~g}$ mouse. Dalteparin was injected subcutaneously once per day for 5 days prior to amyloid induction and then every day following induction until the animals were killed. In addition, enoxaparin sodium injection (Lovenox, Rhone-Poulenc Rorer, Collegeville, PA) average molecular weight 4500 was prepared from a stock solution of $30 \mathrm{mg} / 0.3 \mathrm{ml} \mathrm{(5000} \mathrm{anti-}$ factor Xa International Units). The compound was prepared to $0.01 \mathrm{mg} / 25 \mathrm{~g}$ mouse twice per day beginning 5 days prior to amyloid induction. The doses were comparable to clinically relevant levels [for dalteparin, this corresponds to $16 \mathrm{mg}$ per injection per day and for enoxaparin, $30 \mathrm{mg}$ per injection twice a day (17)]. Subsequently, animals were injected with amyloid enhancing factor (AEF) and silver nitrate after 5 days dosing with LMWH was initiated. LMWH were continued for 5 additional days at which point the animals were killed.

\section{In vitro Fibril Formation}

Mouse SAA proteins were produced in vitro by infection of CV-1 monkey kidney cells with adenoviral vectors as described previously (18). Each purified protein was dissolved in $10 \mathrm{mM}$ Tris- $\mathrm{HCl}$, $\mathrm{pH} 7.4$ at a concentration of $1 \mathrm{mg} / \mathrm{ml}$ and incubated for $72 \mathrm{hr}$ at $37^{\circ} \mathrm{C}$. Samples were dried on glass slides, stained with Congo red, and examined under polarized light for fibril formation $(3,8)$. Additionally, samples were diluted 1:5 or 1:10 with distilled water, placed on Formvar grids, then stained with $1 \%(\mathrm{w} / \mathrm{v})$ uranyl acetate, and examined by electronmicroscopy (Hitachi H-7000). For coincubation studies, amyloid formation was determined by the fluorometric assay using the thioflavin $\mathrm{T}$ (ThT) method (19). Samples were prepared in
$10 \mathrm{mM}$ Tris, $\mathrm{pH} 7.4$ at $1 \mathrm{mg} / \mathrm{ml}, 50 \mathrm{ng} / \mathrm{ml}$ AA fibrils and incubated at $37^{\circ} \mathrm{C}$ for up to $24 \mathrm{hr}$. The samples were assayed in a spectrophotometer at excitation $450 \mathrm{~nm}$ and emission $482 \mathrm{~nm}$. The reaction included $250 \mathrm{nM}$ ThT. Samples were preincubated with enoxaparin or dalteparin at 10-fold molar excess (19).

\section{Induction of AA Amyloid}

Animals were injected with $100 \mu \mathrm{g}$ of AEF into the tail vein followed by injection of $0.5 \mathrm{ml}$ of silver nitrate $(2 \%$ in water) subcutaneously. AEF was prepared as described previously (20). After the times indicated for each experiment, animals were killed, and tissues were excised, placed in formalin, and embedded in paraffin. For experiments using the LMWHs, animals were injected subcutaneously with the indicated doses of compound starting at 5 days prior to amyloid induction and continued until the animals were killed. Eight-micron sections were cut and then subjected to Congo red staining or immunocytochemical analysis with anti-mouse SAA antibodies. Congo red staining was performed as described previously (8). Quantification of amyloid was achieved by Congo red staining and image analysis $(8,16)$. Briefly, the amyloid was quantified by digitizing the immunocytochemical or Congo red image for color (intensity and area) under low power $(20 \times)$ and compared to standard amyloid containing sections $(0,10,20,30,40$, and $50 \%$ of the tissue containing amyloid).

\section{Immunocytochemical Analysis}

For immunocytochemical analysis, sections were blocked with goat serum and incubated with the primary antibody (1:1000 dilution) overnight at $4^{\circ} \mathrm{C}$ (21). The sections were washed and incubated with goat anti-rabbit secondary antibody linked to alkaline phosphatase. After washing, the sections were placed in diaminobenzidine $\mathrm{HCl}$ (DAB) and counterstained with hematoxylin.

\section{Circular Dichroism}

Circular dichroism (CD) measurements were done on a Jasco J-720 spectrophotometer (Jasco Inc., Easton, MD, USA). Measurements were made at $25^{\circ} \mathrm{C}$. Each sample was scanned 10 times and noise reduction applied to remove the high frequency, before calculating molar ellipticities. The voltage to photomultiplier was kept below $500 \mathrm{~V}$ to prevent distortion of the CD spectrum. The data were plotted as described previously $(22,23)$. CD data were obtained from the SAAl.1 in $150 \mathrm{mM} \mathrm{NaCl}$, $20 \mathrm{mM}$ Tris- $\mathrm{HCl}, \mathrm{pH} 8.4,1 \mathrm{mM}$ EDTA, and in the presence of $1 \mathrm{mM}$ added calcium with or without HS $(0.23 \mathrm{mg} / \mathrm{ml})$.

\section{Statistical Analysis}

All data are presented as the mean \pm SEM. Amyloid determinations were analyzed by ANOVA with Fisher's protected least significant difference. A 
probability value of less than 0.05 was considered significant.

\section{Results}

To test the hypothesis that heparin may interfere with amyloid fibrillogenesis, we injected animals with clinical doses of LMWHs. The LMWHs are currently used in antithrombotic therapy in the treatment of unstable angina $(24,25)$. The low molecular weight of these agents (4500-5000) and the clinical availability suggest that they may provide a novel treatment for amyloid diseases. Mice were injected with either enoxaparin $(0.01 \mathrm{mg} / \mathrm{mouse} / \mathrm{twice}$ daily) or dalteparin $(0.006 \mathrm{mg} / \mathrm{mouse} /$ day $)$ for 5 days prior to amyloid induction and continuing until the animals were taken for amyloid analysis (Fig. 1). Mice were injected with AEF (20) and silver nitrate on day 5, and after 5 additional days spleens were collected and examined for amyloid load. Uninjected mice were devoid of amyloid; in stark contrast, mice injected with AEF and silver nitrate had significant amounts of splenic amyloid (Fig. la and lb compared to $1 c$ and ld). Mice injected with enoxaparin, demonstrated a dramatic decrease in amyloid deposition, and dalteparin showed a similar diminution of fibril deposition (Fig. le-h).

Quantification of the amyloid levels in the spleen indicated a significant reduction in mice treated with LMWHs (Fig. li). Dosing of mice with enoxaparin $(0.01 \mathrm{mg} / \mathrm{kg}$ twice daily) or dalteparin $(0.006 \mathrm{mg} / \mathrm{kg} /$ day $)$ slowed the progression of amyloid deposition, resulting in a 4.5- and 4-fold decrease in amyloid detected in the spleen, respectively. Increasing the amount of LMWHs to 2 times the dose further reduced amyloid levels (Fig. li), whereas higher quantities did not further affect the amyloid present (data not shown). Treatment with LMWHs did not alter SAA levels as determined by SDS-PAGE and Western blot analysis, indicating that the effects were on the deposition of SAA into AA fibrils and not at the level of synthesis (Fig. 1j).

Prophylactic treatment will be beneficial to many individuals at risk for amyloidoses; however, therapeutic treatment of individuals with established amyloid is an important consideration. To determine the effects of LMWHs on established amyloid, mice were injected with AEF and silver nitrate and after 5 days LMWH therapy was initiated (Fig. 2). Whereas mice injected with AEF and silver
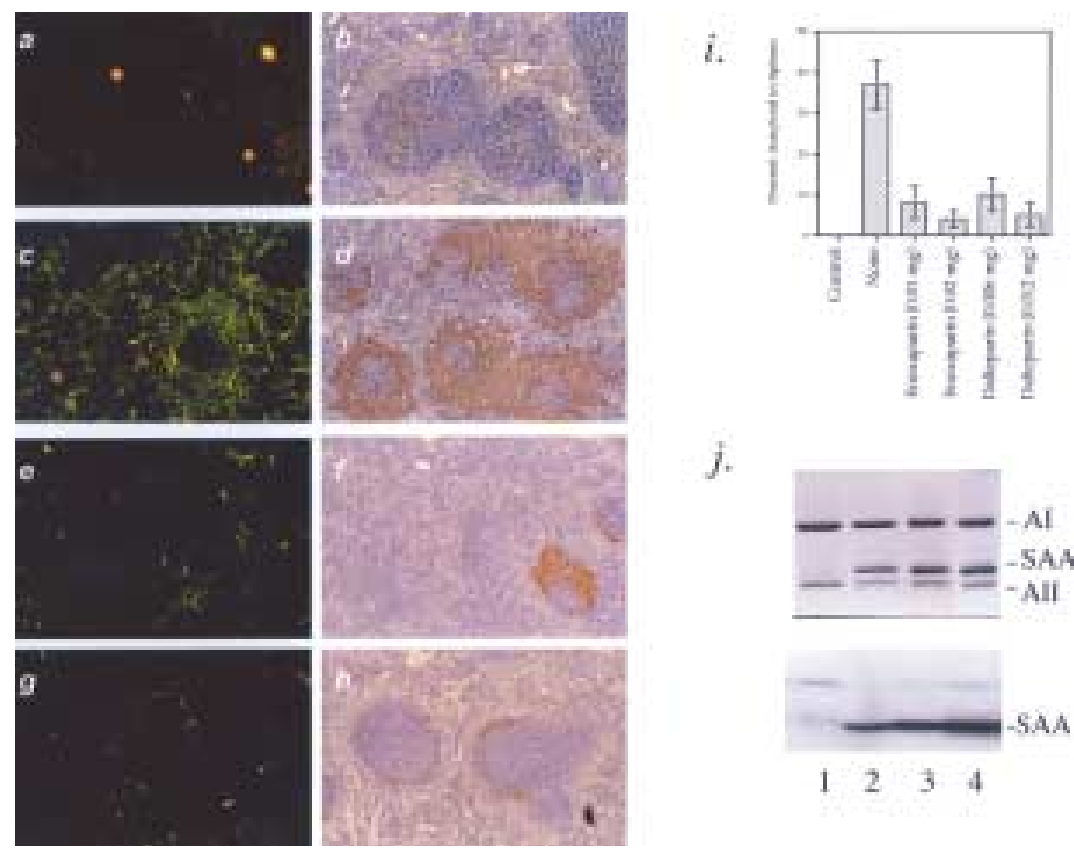

j.

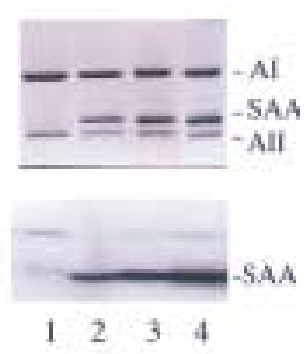

Fig. 1. Effects of LMWH in a mouse model of systemic amyloidosis. Induction of AA amyloid in C57BL/6 mice by injection of AEF and silver nitrate. Congo red staining $(\mathbf{a}, \mathbf{c}, \mathbf{e}, \mathbf{g})$ and immunocytochemical analysis $(\mathbf{b}, \mathbf{d}, \mathbf{f}, \mathbf{h})$ of splenic tissue demonstrates the presence of AA amyloid. (a and b) Control animals without amyloid. (c and d) Presence of amyloid in spleens following AEF and silver nitrate. AA amyloid in the spleen localizes to the perifollicular regions surrounding the splenic nodules. As can be seen, with extensive amyloid the fibrils can extend between nodules (d). (e and r) Mice injected with enoxaparin $(0.01 \mathrm{mg} / 25 \mathrm{~g}$ mouse twice a day) for 5 days prior to induction of amyloidosis and up to day of Killing. ( $\mathrm{g}$ and $\mathbf{j})$ Treatment of mice with dalteparin $(0.006 \mathrm{mg} / 25$ $\mathrm{g}$ mouse per day) as in e and f. (i) Quantification of amyloid deposits in mice in a-h. Amyloid was quantified as described in the Methods section and presented as the mean \pm SEM ( $n=8$ per group). Higher doses of LMWH further attenuated amyloid deposition. Enoxaparin was increased to $0.02 \mathrm{mg}$ per mouse twice a day or dalteparin to $0.012 \mathrm{mg}$ per mouse per day and the amount of amyloid determined. All treated groups are statistically significant at $p<0.001$. (j) Treatment of mice with LMWHs did not alter the expression of SAA. SDS-PAGE (top panel) and Western blot (bottom panel) analysis on HDL isolated from mice. Control (lane 1); AEF/silver nitrate plus saline (lane 2); AEF/silver nitrate plus enoxaparin (lane 3, $0.01 \mathrm{mg}$ per mouse twice daily), or AEF/silver nitrate plus dalteparin (lane 4, $0.006 \mathrm{mg}$ per mouse per day). 


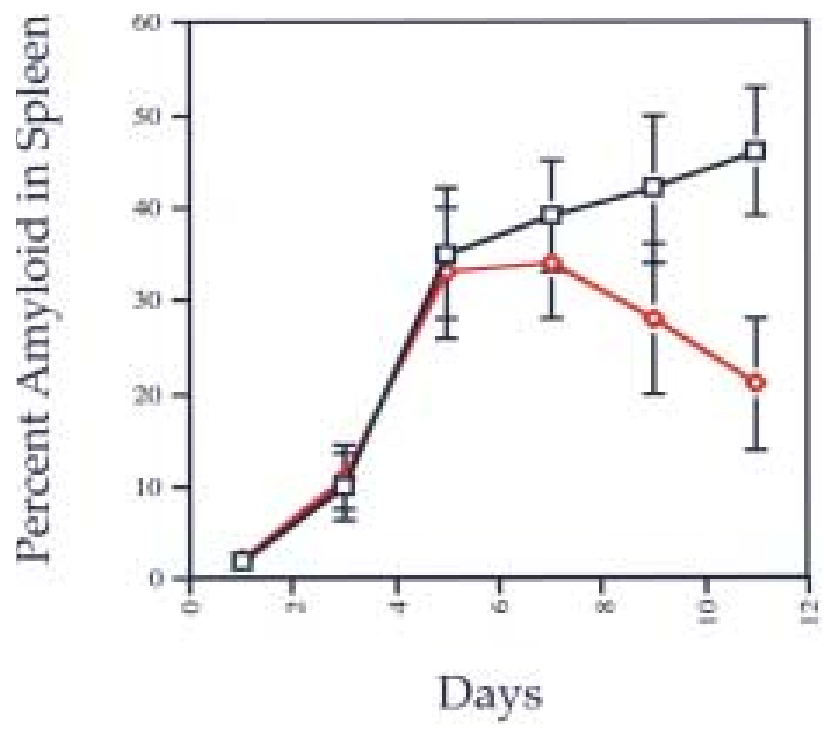

Fig. 2. Resolution of established amyloid in mice. LMWH resolved established amyloid in mice. Mice were treated with AEF and silver nitrate and after 5 days were subjected to subcutaneous injections of LMWH for the indicated times. Animals were killed on days $3,5,7,9$, and 11 , and amyloid was quantified and plotted as mean $\pm \operatorname{SEM}(n=8$ for each time point). Mice were injected with AEF and silver nitrate followed by: saline $(\bullet-\bullet)$; enoxaparin at $0.01 \mathrm{mg}$ per mouse twice a day $(\diamond-\diamond)$. On day 11 , the LMWH-treated group was significantly different from the saline-treated group $(p<0.001)$.

nitrate followed by saline showed a continual increase in amyloid deposition, injection with enoxaparin not only stopped the progression of deposition, but also appeared to facilitate removal of the amyloid fibrils. Inoculation of mice with dalteparin gave rise to similar results with a slowing of the amyloidogenic process and eventually in the reversal of deposition (data not shown).
To demonstrate the ability of the LMWHs to inhibit amyloidogenesis, purified SAA proteins were subjected to in vitro fibrillogenesis in the absence and presence of enoxaparin and dalteparin (Fig. 3). Incubation of fibrillogenic SAAl.1 $(1 \mathrm{mg} / \mathrm{ml})$ at $37^{\circ} \mathrm{C}$ resulted in the formation of amyloid fibrils similar to those seen when fibrils are isolated from amyloidotic spleens [Fig. 3a, Axelrad et al. (20) and data not shown]. Incubation of SAAl.1 in the presence of a 10-fold molar excess of dalteparin (Fig. 3b) or enoxaparin (Fig. 3c) limited fibril formation in vitro. Quantification of the fibril extension showed a dramatic decrease in fibrillogenesis in the presence of the LMWH molecules (Fig. 3d). In addition, fibrillogenesis was inhibited when $\mathrm{A} \beta$ peptides were utilized (Fig. 3e). As with the SAA proteins, enoxaparin and dalteparin were capable of blocking fibril formation of the $\mathrm{A} \beta$ peptide in Alzheimer's disease, indicating that the LMWHs are not specific for AA amyloid and may provide a novel treatment for AD. LMWHs were also capable of preventing the formation of $\beta$-sheet structure as determined by circular dichroism analysis (Table 1). As shown in the table, HS interacts with specific protein to induce a shift in protein structure from random coil to $\beta$-sheet, and in the presence of LMWH this shift was inhibited. This suggests that LWMH may prevent fibrillogenesis by not allowing for structural changes necessary for fibril interaction and in established amyloid may interfere with the assembly resulting in a shift back to a nonfibrillar form.

\section{Discussion}

We have here demonstrated that LMWHs are capable of interacting with amyloidogenic proteins and inhibiting the fibrillogenic properties of the proteins and disrupting amyloid deposition in vivo. Furthermore, we have shown that LMWHs can slow

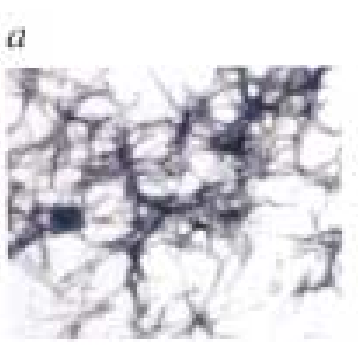

b

d

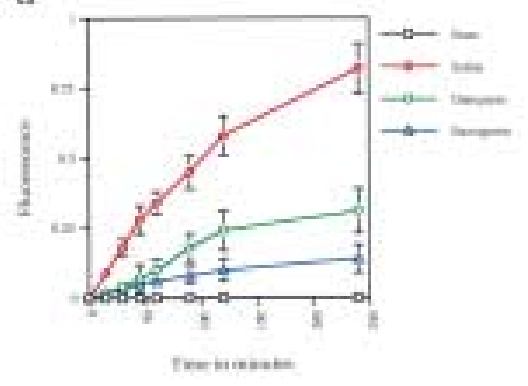

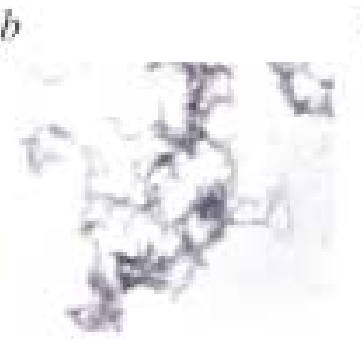

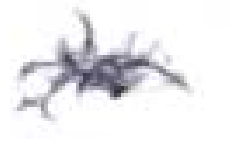

$\varepsilon$

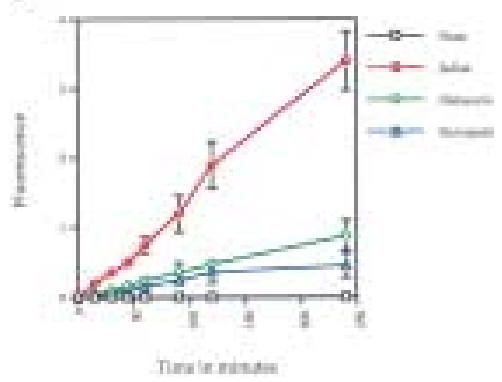

Fig. 3. Inhibition of in vitro fibril formation with LMWH. Purified SAA $1.1(1 \mathrm{mg} / \mathrm{ml})$ proteins were incubated in the presence of a 10 -fold molar excess of $\mathrm{LMWH}$ for $72 \mathrm{hr}$ at $37^{\circ} \mathrm{C}$ and examined by negative stain electron microscopy. (a) SAA fibril formation in the absence of LMWH. (b) Fibril formation in the presence of dalteparin demonstrated a dramatic decrease in fibril formation. (c) Incubation of the SAA proteins with enoxaparin prevented the ability of the SAA proteins to aggregate. None indicates no SAA or amyloid fibrils in the assay. (d) Fluorometric analysis of fibril formation using SAA proteins. SAAl.1 $(1 \mathrm{mg} / \mathrm{ml})$ proteins were incubated with AA fibrils $(50 \mathrm{ng} / \mathrm{ml})$ with or without LMWH (10-fold molar excess) at $37^{\circ} \mathrm{C}$ for up to $4 \mathrm{hr}$. (e) Fluorometric analysis of fibril formation with $\mathrm{A} \beta$ peptides. $\mathrm{A} \beta$ peptides $(1 \mathrm{mg} / \mathrm{ml})$ were incubated as described in $\mathbf{d}$. 
Table 1. For UV CD data for SAAl.1 in the presence of HS \pm LMWH

\begin{tabular}{lcccc}
\hline & \multicolumn{3}{c}{ Proportion of Structure as } \\
\cline { 2 - 5 } Solvent Conditions & $\alpha$-Helix & $\beta$-Sheet & $\beta$-Turn & Remainder \\
\hline SAAl.1 & 0.19 & 0.42 & 0.16 & 0.23 \\
SAA1.1 + HS & 0.17 & 0.60 & 0.18 & 0.05 \\
SAAl.1 + HS + LWMH & 0.18 & 0.41 & 0.15 & 0.26 \\
\end{tabular}

CD spectra were analyzed by Cotrin program version 1.0 of Provencher and Glockner (32). Data are at 1-nm intervals made over the range of $190-240 \mathrm{~nm}$ in a $0.05-\mathrm{cm}$ path length cell. The free calcium concentration was $1 \mathrm{mM}$ and the HS concentration was $0.23 \mathrm{mg} / \mathrm{ml}$. LMWH (enoxaparin) was used at a concentration of $2 \mathrm{mg} / \mathrm{ml}$. The HS to protein ratio was approximately 1 to 2 .

or stop the progress of amyloidogenesis and accelerate the removal of established amyloid. Understanding the principals involved in the inhibition of fibrillogenesis may allow the development of derivatives that may limit the progression of amyloid diseases.

Studies have shown that HS proteoglycans interact with amyloidogenic proteins and facilitate fibrillogenesis by altering the structural features of the molecules. Binding of fibrillogenic SAAl.1 to HS resulted in an increase in $\beta$-sheet structure whereas the nonfibrillogenic SAA2.1 or SAA2.2 were not structurally altered by interaction with HS $(22,26)$. Subsequent studies have shown that SAA can bind with high affinity and specificity to heparin and HS, indicating that this interaction may be important in the amyloidogenicity of the proteins (27). In addition, high-affinity interactions between the Alzheimer's $\beta$-amyloid precursor protein ( $\beta$-APP) and HSPG have been detected and that this binding can be inhibited by heparin (28). Deletion mutagenesis identified two heparin-binding domains in the APP protein, and synthetic peptides to candidate heparin-binding regions identified at least four heparin binding sites (29). The binding of HSPG to amylin (i.e., IAPP) enhanced fibril formation in a dose-dependent manner. Furthermore, HSPG interacts with amylin in a highly specific fashion and the association was abolished in the presence of heparin (30). We hypothesize that indeed the interaction between amyloid proteins and HSPG may be important for fibrillogenesis.

There is some controversy over the role of heparin, derivatives of heparin, and sulfated compounds in the amyloidogenesis. Initial studies by Kisilevsky et al. demonstrated that polyvinylsulfate and aliphatic polysulfonates could interfere with HSPG-induced $\mathrm{A} \beta$ fibril formation and prevent the accumulation of AA amyloid in mice $(16,31,32)$. Recently, one study showed that removal of the sulfate moieties from heparin resulted in a complete loss in the enhanced $A \beta$ fibrillogenesis (33). In addition, compounds such as chondroitin-4-sulfate, dermatin sulfate, dextran sulfate, and pentosan polysulfate all enhanced the fibrillogenic capacity of the $\mathrm{A} \beta$ peptide significantly $(33,34)$. On the other hand, Watson et al. (35) found that, using affinity co-electrophoresis, heparin bound with high affinity to the $\mathrm{A} \beta$ peptide and to amylin and promoted fibril formation. Shuvaev and Siest (36) showed that LMWHs stimulated the formation of $\mathrm{A} \beta$ fibrils, but that this activity was inhibited by high-affinity interactions with apolipoprotein E.

LMWHs have been implicated in altering the structural and synthetic properties of amyloidogenic proteins. HS proteoglycans are a component of the plaques associated with prion diseases and this interaction might have physiologic significance (37). HS can increase the concentration of prion proteins (PrP) in neuroblastoma cells; LMWHs appear to inhibit the synthesis of PrPSc in scrapie infected cells. In addition, LMWHs were capable of converting PrPSc back to PrP as determined by the lack of infectivity of the molecules. Subsequently, data indicate that fragments of LMWHs (heparan disaccharides) were capable of blocking APP synthesis and inhibited the binding of heparin to APP (38). To help determine the role of LMWHs in amyloidogenesis, we examined the effects of clinically available LMWHs on fibril formation both in vitro and in vivo using an animal model of AA amyloid.

In the current study, LMWHs did have a dramatic effect on the fibrillogenic properties of the amyloidogenic proteins. CD analysis demonstrated that LMWH can interfere with the in vitro HS stimulated $\beta$-sheet structure and this in turn inhibits the fibrillogenic capabilities of the molecules. This translated into an inhibition of amyloid deposition by preventing fibrillogenesis in vivo and by disrupting the preformed fibrils allowing for rapid degradation of amyloid fibrils. These observations contribute to a growing body of evidence implicating HS proteoglycans in the pathogenesis of amyloid diseases, including Alzheimer's, which may provide a potential target for therapeutic intervention to disrupt common pathogenetic mechanisms. 


\section{Acknowledgments}

The authors wish to thank Mr. John Cranfill and Ms. Connie Gerardot for expert technical assistance. This work was supported by grants from the USPHS (NS31220 and AG12891) and the Stroke Program of the Sanders-Brown Center on Aging.

\section{References}

1. Selkoe DJ. (1997) Alzheimer's disease: genotypes, phenotypes, and treatments. Science 275: 630-631.

2. Haass C, Selkoe DJ. (1993) Cellular processing of $\beta$-amyloid precursor protein and the genesis of amyloid $\beta$-peptide. Cell 75: 1039-1042.

3. Yan SD, Zhu H, Golabek A, et al. (2000) Receptor-dependent cell stress and amyloid accumulation in systemic amyloidosis. Nat. Med. 6: 643-651.

4. Selkoe DJ. (1999) Translating cell biology into therapeutic advances in Alzheimer's disease. Nature 399: A23-A31.

5. Kindy MS, deBeer FC. (2000) Amyloidosis. In: Massry SG, Glassock RJ, eds. Textbook of nephrology. Philadelphia: Lippincott Williams and Wilkins.

6. Kisilevsky R. (1993) Amyloidogenesis-A critical review. In: Kisilevsky R, Benson MD, Frangione B, Gauldie J, Muckle TJ, and Young ID, eds. Amyloid and amyloidosis. New York: Parthenon.

7. Botto M, Hawkins PN, Bickerstaff MC, Herbert J, et al. (1997) Amyloid deposition is delayed in mice with targeted deletion of the serum amyloid P component gene. Nat. Med. 3: 855-859.

8. Kindy MS, Rader DL. (1998) Reduction in amyloid A amyloid formation in apolipoprotein-E-deficient mice. Am. J. Pathol. 152 1387-1395.

9. Fraser PE, Nguyen JT, Chin DT, Kirschner DA. (1992) Effects of sulfate ions on Alzheimer-beta/A4 peptide assembliesimplications for amyloid fibril-proteoglycan interactions. J. Neruochem. 59: 1531-1540.

10. Tennent GA, Lovat LB, Pepys MB. (1995) Serum amyloid P component prevents proteolysis of the amyloid fibrils of Alzheimer's disease and systemic amyloidosis. Proc. Natl. Acad. Sci. U.S.A. 92: 4299-4303.

11. Wood SJ, Chan W, Wetzel R. (1996) Seeding of A beta fibril formation is inhibited by all three isotypes of apolipoprotein E. Biochemistry 35: 12623-12628.

12. Ma J, Yee A, Brewer HB, Das S, Potter H. (1994) Amyloidassociated proteins alpha 1-antichymotrypsin and apolipoprotein E promote assembly of Alzheimer beta-protein into filaments. Nature 372: 92-94.

13. Bales KR, Verina T, Dodel RC, et al. (1997) Lack of apolipoprotein $\mathrm{E}$ dramatically reduces amyloid beta-peptide deposition. Nat. Genet. 17: 263-264.

14. Magnus JH, Stenstad T, Husby G, Kolset SO. (1992) Isolation and partial characterization of heparan sulphate proteoglycans from human hepatic amyloid. Biochem. J. 288: 225-231.

15. Lyon AW, Narindrasorasak S, Young ID, et al. (1991) Codeposition of basement membrane components during the induction of murine splenic AA amyloid. Lab. Invest. 64: 785-790.

16. Kisilevsky R, Lemieux LJ, Fraser PE, Kong $X$, Hultin PG, Szarek WA. (1995) Arresting amyloidosis in vivo using smallmolecule anionic sulphonates or sulphates: implications for Alzheimer's disease. Nat. Med. 1: 143-148.

17. Physician's desk reference, 55th ed. (2001) Montvale, N.J.: Medical Economics; pp. 2613, 713.

18. Kindy MS, King AR, Yu J, Gerardot C, Whitley J, deBeer FC. (1998) Adenoviral expression of murine serum amyloid A proteins to study amyloid fibrillogenesis. Biochem. J. 332: 72 1-728.

19. Chiba T, Kogishi K, Wang J, et al. (1999) Mouse senile amyloid deposition is suppressed by adenovirus-mediated overexpression of amyloid-resistant apolipoprotein A-II. Am. J. Pathol. 155: 1319-1326.
20. Axelrad MA, Kisilevsky R, Willmer J, Chen SJ, Skinner M. (1982) Further characterization of amyloid-enhancing factor. Lab. Invest. 47: 139-146.

21. Kindy MS, de Beer FC. (1999) A mouse model for serum amyloid A amyloidosis. Meth. Enzymol. 309: 701-716.

22. De Beer MC, de Beer FC, McCubbin WD, Kay CM, Kindy MS. (1993) Structural prerequisites for amyloid A fibril formation. J. Biol. Chem. 268: 20606-20612.

23. Provencher S, Glockner J. (1981) Estimation of globular protein secondary structure from circular dichroism. Biochemistry 20: $33-37$.

24. Fragmin During Instability in Coronary Artery Disease (FRISC) Study Group. (1996) Low-molecular-weight heparin during instability in coronary artery disease. Lancet 347: 561-568 (1996).

25. Cohen M, Demers C, Gurfinkel EP, et al. (1997) A comparison of low-molecular-weight heparin with unfractionated heparin for unstable coronary artery disease. N. Engl. J. Med. 337: 447452.

26. McCubbin WD, Kay CM, Narindrasorasak S, Kisilevsky R. (1988) Circular-dichroism studies on two murine serum amyloid A proteins. Biochem. J. 256: 775-783.

27. Ancsin JB, Kisilevsky R. (1999) The heparin/heparan sulfatebinding site on apo-serum amyloid A. implications for the therapeutic intervention of amyloidosis. J. Biol. Chem. 274: 7172-7181.

28. Narindrasorasak S, Lowery D, Gonzalez-De-Whitt P, Poorman RA, Greenberg B, Kisilevsky R. (1991) High affinity interactions between the Alzheimer's beta-amyloid precursor proteins and the basement membrane form of heparan sulfate proteoglycan. J. Biol. Chem. 266: 12878-12883.

29. Clarris HJ, Cappai R, Heffernan D, Bryreuther K, Masters CL Small DH. (1997) Identification of heparin-binding domains in the amyloid precursor protein of Alzheimer's disease by deletion mutagenesis and peptide mapping. J. Neurochem. 68: 1164-1172.

30. Castillo GM, Cummings JA, Yang W, et al. (1998) Sulfate content and specific glycosaminoglycan backbone of perlecan are critical for perlecan's enhancement of islet amyloid polypeptide (amylin) fibril formation. Diabetes 47: 612620.

31. Inoue S, Hultin PG, Szarek WA, Kisilevsky R. (1996) Effect of poly(vinylsulfonate) on murine AA amyloid: a highresolution ultrastructural study. Lab. Invest. 74: 10811090.

32. Leveugle B, Scanameo A, Ding W, Fillit H. (1994) Binding of heparan sulfate proteoglycan to $\beta$-amyloid peptide: inhibition by potentially therapeutic polysulfated compounds. Neuroreport 5: 1389-1392.

33. Castillo GM, Lukito W, Wight TN, Snow AD. (1999) The sulfate moieties of glycosaminoglycans are critical for the enhancement of beta-amyloid protein fibril formation. J. Neurochem. 72: 16811687.

34. McLaurin J, Franklin T, Zhang X, Deng J, Fraser PE. (1999) Interactions of Alzheimer amyloid-beta peptides with glycosaminoglycans effects on nucleation and growth. Eur. J. Biochem. 266: 1101-1110.

35. Watson DJ, Lander AD, Selkoe DJ. (1997) Heparin-binding properties of the amyloidogenic peptides $\mathrm{A} \beta$ and amylin. J. Biol. Chem. 272: 31617-31624.

36. Shuvaev VV, Siest G. (2000) Heparin specifically inhibits binding of apolipoprotein E to amyloid $\beta$-peptide. Neurosci. Lett. 280: 131-134.

37. Gabizon R, Meiner Z, Halimi M, Ben-Sasson SA. (1993) Heparin-like molecules bind differentially to prion-proteins and changes their intracellular metabolic fate. J. Cell. Physiol. 157: 319-325.

38. Leveugle B, Ding W, Laurence F, et al. (1998) Heparin oligosaccharides that pass the blood-brain barrier inhibit $\beta$-amyloid precursor protein secretion and heparin binding to $\beta$-amyloid peptide. J. Neurochem. 70: 736-744. 